\title{
Biodeterioration Potentials of Microorganisms Isolated from Pig Manure Obtained at Awka, Nigeria
}

\author{
Onuorah Samuel ${ }^{*}$, Soludo Christian, Odibo Frederick
}

Department of Applied Microbiology and Brewing, Nnamdi Azikiwe University, Nigeria

Copyright $@ 2017$ by authors, all rights reserved. Authors agree that this article remains permanently open access under the terms of the Creative Commons Attribution License 4.0 International License

\begin{abstract}
The biodeterioration potentials of microorganisms isolated from pig manure was studied using standard methods. The heterotrophic microorganisms isolated from the manure were Escherichia coli, Micrococcus luteus, Enterococcus faecalis, Staphylococcus aureus, Proteus vulgaris, Shigella flexneri, Serratia marcescens, Pseudomonas aeruginosa, Aspergillus niger, Cladosporium resinae, Penicillium expansum, Trichoderma herbarum and Candida tropicalis while all the organisms except Escherichia coli and Staphylococcus aureus were the hydrocarbon - utilizing isolates. The most active degraders were Pseudomonas aeruginosa, Micrococcus luteus, Aspergillus niger, Cladosporium resinae and the bacterial and fungal consortia that produced the highest turbidity and clarity indicating hydrocarbon utilization. The growth profile of Micrococcus luteus, Pseudomonas aeruginosa, Aspergillus niger and Cladosporium resinae as well as the fungal and bacterial consortia during 35 days of growth in mineral salts-oil medium showed that there was a decrease in the $\mathrm{pH}$ and an increase in the viable count of the medium. The highest percentage degradation of the crude oil was by the bacterial consortium (62.0\%). This work showed that Pig manure which is generally regarded as a waste product harbours diverse bacteria and fungi which will be useful in remediating oil-polluted environments when applied singly and as a consortia.
\end{abstract}

Keywords Biodeterioration, Potentials, Microorganisms, Pig Manure, Awka, Nigeria

\section{Introduction}

The widespread and massive use of petroleum hydrocarbons over the past two centuries has left a legacy of contaminated sites which require remediation due to the threat to human health and the environment [1]. Soil hydrocarbon contamination is commonly caused by leaking underground storage tanks, pipelines, oil refineries, land disposal facilities, wood treatment facilities, former manufactured gas plant sites [2] and water that washes contaminants from an area containing hazardous substances and depositing it in the soil as it flows over or through it [3]. Usually, contaminants in the soil are physically or chemically attached to soil particles or are trapped in the small spaces between soil particles [3].

Petroleum hydrocarbon contamination of the lithosphere has detrimental effects on both the terrestrial and aquatic environments, affecting commercial and subsistence farming and fishing. The contaminants exhibit toxic, mutagenic and carcinogenic properties as they accumulate in food chains [4] and sometimes in aquatic organisms [5]. These adverse effects result in land degradation and water amendments, limiting land use and damaging the ecosystem [6].

Hydrocarbons, not only are found in petroleum polluted areas but there are significant quantities of aliphatic and aromatic hydrocarbons in most soils and sediments [7]. Since hydrocarbon is a natural product as well as a pollutant, it is not surprising that hydrocarbon-oxidizing bacteria are widely distributed in nature, though the alkane fraction is the most biodegradable [8].

Microorganisms in the environment especially the lithosphere, attack and digest petroleum hydrocarbons, forming the basis for the field of bioremediation which is one of the rapidly growing areas of environmental microbiology that has been used for cleaning up pollutants.

Bacteria and fungi have been found to be very useful in bioremediation process. Among the diversity of microorganisms responsible for high degradation of pollutants, Bacillus subtilis and Pseudomonas aeruginosa have the capability to degrade many different pollutants [9] and can be employed in the bioremediation of crude oil polluted soil. Members of the genera Aspergillus and Candida are capable of mineralizing recalcitrant.

All over the world, petroleum has been found where the geologic environment favoured heavy accumulation of plant and animal matter as a source of organic carbon [3]. Petroleum-degrading microorganisms are bacterial and fungal species with an inherent capacity to assimilate petroleum hydrocarbons and their products. The presence of crude oil degraders is not restricted to a particular ecosystem. 
The distribution of these microbes in nature is known to be widespread in such ecosystems as soils, sediments and lubricating oil $[4,10,11]$.

Pig manure is an organic waste which is disposed off on the terrestrial environment. Although the manure is rich in nutrients needed for increased crop yield, it contributes to environmental and health pollution through the odour, flies and pathogens it generates. The use of microorganisms in the manure in the remediation of crude oil-impacted environments will minimize the problems associated with the waste and lead to a drastic reduction in its volume in the environment, hence in this work, the biodeterioration potentials of microorganisms isolated from Pig manure obtained from Awka, Nigeria was studied.

\section{Materials and Methods}

\subsection{Samples Collection and Processing}

Five samples of pig manure were collected from each of three piggery farms in Awka, Nigeria. The samples were collected in separate sterile polythene bags. They were air-dried, ground and conveyed on ice packs to the laboratory where they were analysed microbiologically within 24 hours of collection. The crude oil used in this experiment was obtained from Eleme Oil Company, a petrochemical company situated at Eleme Local Government Area of Rivers State, Nigeria.

\subsection{Isolation of the Heterotrophic Bacteria and Fungi}

One gram of the pig manure was measured using a weighing balance and introduced into a test tube. Ten folds serial dilution of the sample was carried out using sterile distilled water. One milliliter aliquot of the diluted sample $\left(10^{5}\right)$ was plated out using the pour plate technique into Petri dishes containing nutrient agar (NA) with $0.05 \mathrm{mg} / \mathrm{l}$ of nystatin to inhibit fungal growth and Sabouraud dextrose agar (SDA) containing $0.05 \mathrm{mg} / \mathrm{l}$ of chloramphenicol to inhibit bacterial growth. The Petri dishes were covered and incubated in an inverted position at $28^{\circ} \mathrm{C}$ for 48 hours for the bacteria and $28^{\circ} \mathrm{C}$ for 96 hours for the fungi. The colonies that developed after the incubation period were subcultured on sterile nutrient agar and Sabouraud dextrose agar plates and later stored on NA for bacteria and SDA slants for fungi for characterization and identification.

\subsection{Isolation of the Petroleum Hydrocarbon- Utilizing Bacteria and Fungi}

One milliliter aliquot of the serially- diluted sample was plated out using the pour plate method into Petri dishes of nutrient agar containing $0.05 \mathrm{mg} / \mathrm{l}$ of nystatin to inhibit fungal growth and Sabouraud dextrose agar containing $0.05 \mathrm{mg} / \mathrm{l}$ of chloramphenicol to inhibit bacterial growth. Whatman filter papers were soaked in crude oil and inserted at the cover of the Petri dishes to supply hydrocarbons to the organisms by vapor phase transfer. The Petri dishes were thereafter covered and incubated in an inverted position at $28^{\circ} \mathrm{C}$ for seven days and the colonies that developed were purified and stored on nutrient agar and Sabouraud dextrose agar slants for the hydrocarbon- utilizing bacteria and fungi respectively.

\subsection{Characterization and Identification of the Microbial Isolates}

The bacterial isolates were characterized morphologically, biochemically and molecularly. The molecular characterization was based on 16SrDNA sequencing using Fasta algorithm. The tests carried out were Gram Stain, motility test, catalase test, coagulase test, citrate utilization test, oxidase test, indole test, methyl red test, voges proskaeur, spore test, and sugars (glucose, sucrose, lactose and mannitol) fermentation test as done by Cheesbrough [12]. Characterization and identification of the fungi were done using the fungal atlas, lactophenol cotton blue staining technique, slide culture technique, urease test, motility test, sugars fermentation test and germ tube test.

\subsubsection{Gram Stain}

A thin smear of the test organism was made on a clean grease-free slide. It was allowed to air-dry and then heat-fixed by passing it over a Bunsen flame thrice. The slide was carefully placed on a staining rack and flooded with crystal violet solution and left for 60 seconds before being washed off with clean water. Lugol's iodine solution was added and left for 60 seconds and washed off with clean water. The slide was decolorized with acetone for ten seconds, rinsed with clean water and counterstained with safranin. It was allowed to stand for 60 seconds, washed off with clean water and allowed to dry in air. The slide was thereafter examined under the oil immersion objective lens of the microscope.

\subsubsection{Motility Test}

Semi-solid nutrient agar was prepared, autoclaved, distributed in test tubes and allowed to cool. The tubes were stab-inoculated with the organisms with a sterile straight wire and incubated at $37^{\circ} \mathrm{C}$ for 24 hours. The bacteria that grew along the straight line of the stab were the non-motile ones while the motile bacteria grew away from the line of the stab.

\subsubsection{Catalase Test}

A drop of 3\% hydrogen peroxide solution was introduced on a microscope slide and a loopful of the organism was added to it. The appearance of sustained bubbles indicated a positive reaction while the absence of bubbles indicated a negative result.

\subsubsection{Indole Test}

Five milliliters of peptone water were transferred into a test tube and autoclaved at $121^{\circ} \mathrm{C}$ for fifteen minutes and allowed to cool. The test isolate was thereafter inoculated into the broth which was incubated at $37^{\circ} \mathrm{C}$ for 24 hours. 
Three drops of kovac's reagent were added to the medium. A pink to red coloration indicated a positive result while the presence of yellow colour indicated a negative result.

\subsubsection{Coagulase Test}

A drop of distilled water was placed on a clean grease free glass slide and a test organism was emulsified in it. One milliliter of plasma was added to it and it was mixed gently. The clumping of the organism within 10seconds indicated a positive result.

\subsubsection{Oxidase Test}

A piece of filter paper was soaked with some drops of oxidase reagent (tetramethyl phenelene diamine dihydrochloride). The test organism was then smeared on the soaked filter paper. A change to deep purple colour within 10 seconds indicated a positive reaction.

\subsubsection{Methyl Red Test}

The test organism was introduced into glucose phosphate peptone water and incubated at $37^{\circ} \mathrm{C}$ for 48 hours. Five drops of methyl red reagent were added, mixed and the result read. The red coloration indicated a positive result while a yellow coloration indicated a negative result.

\subsubsection{Voges Proskaeur Test}

The test organism was introduced into glucose phosphate peptone water and incubated at $37^{\circ} \mathrm{C}$ for 48 hours. Five drops of Baritt A (alpha-naphtol) and Baritt B (potassium hydroxide) reagents were added, mixed and the result read. A pink burgundy coloration indicated a positive result.

\subsubsection{Citrate Utilization Test}

The test organism was streaked on Simmon citrate agar and incubated at $37^{\circ} \mathrm{C}$ for 24 hours. A change in colour of the medium from green to blue indicated a positive result.

\subsubsection{Sugar Fermentation Test}

Peptone water was prepared according to the manufacturer's instruction and two drops of bromothymol blue indicator solution were added. The test sugar (1\%) was also added and the mixture was distributed into test tubes containing durham tubes. The tubes were sterilized by autoclaving at $121^{\circ} \mathrm{C}$ for fifteen minutes and allowed to cool. Upon cooling, the tubes were inoculated with the test organism and incubated at $37^{\circ} \mathrm{C}$ for 48 hours. A colour change from blue to yellow indicated acid production while gas production was indicated by a void in the durham tubes.

\subsubsection{Urease Test}

Urea agar was the growth medium and it was prepared according to the manufacturer's specification. It was heated to boiling on a hot plate, introduced into McCartney bottles and autoclaved at $121^{\circ} \mathrm{C}$ for fifteen minutes. Upon cooling, the isolate was aseptically inoculated into the bottles which were then incubated at $37^{\circ} \mathrm{C}$ for 7 days. A change of colour from light pink to light yellow indicated the production of urease.

\subsubsection{Lactophenol Cotton Blue Test}

A drop of lactophenol cotton blue solution was placed on a clean grease-free slide. A sterilized straight wire was used to transfer and properly mix the test fungus with the solution on the slide. A cover slip was placed on the slide and the excess stain was blotted. The slide was thereafter viewed under the X40 objective lens of the microscope for the presence of hyphae, mycelia and spores.

\subsubsection{Slide Culture Technique}

Sterile Sabouraud dextrose agar was prepared and inoculated with a mold isolate. A cover slip was inserted beside the mold and incubated at $28^{\circ} \mathrm{C}$ in an inverted position for 5 days. The cover slip was placed on a slide containing a drop of lactophenol cotton blue solution and examined with $\mathrm{X} 10$ and X40 objective lens of the microscope for the presence of the fungal features.

\subsubsection{Germ Tube Test}

$0.5 \mathrm{ml}$ of human serum was dispensed into a test tube. The serum was inoculated with a yeast isolate and the test tube was incubated at $37^{0} \mathrm{C}$ for 3 hours. A Pasteur pipette was used to transfer a drop of the serum-yeast culture to a clean slide which was thereafter covered with a cover slip and examined using X10 and X40 objective lens of the microscope. Growing yeast cells in the form of tube-like outgrowth from the cells were recorded as a positive result.

\subsubsection{Spore Test}

A bacterial film was made on a clean grease-free sterile glass slide, air-dried and fixed with minimal flaming. The slide was placed on the rim of a beaker of boiling water, with the bacterial film uppermost. The film was flooded with $0.5 \%$ aqueous solution of malachite green when large droplets have condensed on the underside of the slide and left to act for 10 minutes while the water continued to boil. The slide was washed with cold water and treated with a $0.5 \%$ safranin solution and left for 60 seconds. The slide was then washed with water, dried and viewed under the microscope. This method coloured the spores green and the vegetative bacilli red.

\subsection{Screening Test for Hydrocarbon Utilization by the Microbial Isolates}

The mineral salts medium used by Olukunle [13] was used. It was composed of the following (g/l): $\mathrm{NaCl}, 10.0$, $\mathrm{MgSO}_{4} .7 \mathrm{H}_{2} \mathrm{O}, 0.42 ; \mathrm{KCl}, 0.29 ; \mathrm{KH}_{2} \mathrm{PO}_{4}, 0.83 ; \mathrm{NaHPO}_{4}$, 1.25; $\mathrm{NaNO}_{3}, 0.42$; deionized water, 1 liter and Agar, 20. The medium was contained in test tubes in $9 \mathrm{ml}$ amounts and $1 \mathrm{ml}$ of crude oil was added to each of the tubes. The tubes were capped and sterilized by autoclaving at $121^{\circ} \mathrm{C}$ for fifteen minutes and allowed to cool. Upon cooling, the tubes were inoculated with the microbial isolates singly and as consortia. Tubes containing the mineral salts medium and crude oil only were used as controls. All the tubes were 
incubated in a rotary shaker at 75rpm for fourteen days at $28^{0} \mathrm{C}$ after which the tubes containing the bacterial isolates were examined for turbidity while those containing the fungi were checked for clarity.

\subsection{Effect of Varying Crude Oil Concentrations on the Growth of the Hydrocarbon-Utilizing Microbial Isolates}

Varying concentrations (1.0\%, 5.0\%, 10.0\%) of crude oil were separately added to nutrient broth in thirty three test tubes as done by Amadi and Antai [14]. The first set of eleven test tubes each received $9.9 \mathrm{ml}$ of nutrient broth and $0.1 \mathrm{ml}(1.0 \%)$ of crude oil while the second set of eleven test tubes each received $9.5 \mathrm{ml}$ of nutrient broth and $0.5 \mathrm{ml}(0.5 \%)$ of crude oil. The third set of eleven test tubes each received $9.0 \mathrm{ml}$ of nutrient broth and $1.0 \mathrm{ml}(10.0 \%)$ of crude oil. The test tubes were sterilized by autoclaving at $121^{\circ} \mathrm{C}$ for fifteen minutes and allowed to cool. Upon cooling, the test tubes were inoculated with the microbial isolates singly. Three control tubes containing nutrient broth and 1.0\%, 5.0\% and $10.0 \%$ crude oil respectively remained uninoculated. All the tubes were incubated at $28^{0} \mathrm{C}$ for fourteen days in a rotary shaker at $75 \mathrm{rpm}$ after which they were examined for turbidity for bacteria and clarity for fungi.

\subsection{Effect of Varying pH of Medium on the Growth of Hydrocarbon-Utilizing Microbial Isolates}

Four hundred milliliters of the mineral salts medium described by Mills et al [15] were prepared, autoclaved and transferred into three $125 \mathrm{ml}$ screw-capped bottles in $120 \mathrm{ml}$ quantities. The $\mathrm{pH}$ of the medium in the first bottle was adjusted to 3.0 by adding $0.6 \mathrm{ml}$ of dilute hydrochloric acid. The $\mathrm{pH}$ of the medium in the second bottle was in the neutral range (7.0) while the $\mathrm{pH}$ of the medium in the third bottle was adjusted to 10.0 by adding $2.0 \mathrm{ml}$ of $0.1 \mathrm{M}$ solution of sodium hydroxide to it.

The medium in each of the bottles was transferred into eleven sterile test tubes in $9.9 \mathrm{ml}$ quantities after which $0.1 \mathrm{ml}$ crude oil (1.0\%) sterilized by autoclaving was added to each of the tubes. The microbial isolates were thereafter inoculated aseptically singly into the medium. Incubation was carried out at $28^{\circ} \mathrm{C}$ for fourteen days in a rotary shaker at 75rpm after which the tubes was examined for turbidity and clarity for the bacteria and fungi respectively.

\subsection{Effect of Varying Concentrations of Nutrients on the Growth of the Hydrocarbon-Utilizing Microbial Isolates}

The effect of varying concentrations of inorganic fertilizer (NPK) and Pig manure on the growth of the hydrocarbon-utilizing microbial isolates was determined using a basal medium described by Mills et al [15]. The medium was dispensed in $100 \mathrm{ml}$ quantities into two conical flasks. Thereafter, Pig manure was introduced into the flasks at concentrations of $1.0 \mathrm{~g}, 5.0 \mathrm{~g}$ and $10.0 \mathrm{~g}$ respectively. The content of each flask was transferred in $9 \mathrm{ml}$ quantities into eleven test tubes and $1.0 \mathrm{ml}(1.0 \%)$ of crude oil added as the carbon source. The test tubes were sterilized by autoclaving at $121^{\circ} \mathrm{C}$ for fifteen minutes and allowed to cool after which they were inoculated with the microbial isolates individually and incubated at $28^{\circ} \mathrm{C}$ for fourteen days in a rotary shaker at $75 \mathrm{rpm}$. The microbial growth responses were determined by reading the optical density at 560nm for the bacteria using the Spectrophotometer and determining the biomass in the case of fungi. This procedure used for Pig manure was employed in the case of inorganic fertilizer.

\subsubsection{Determination of the Fungal Biomass}

This was performed as described by Amanchukwu et al [16]. The content of each flask containing a fungus was passed through a filter paper, which retained the fungus while it allowed the medium to pass through it. The fungus was transferred into a crucible of known weight and their weight determined. Drying was done at $70^{\circ} \mathrm{C}$ in a hot air oven to a constant weight. The fungal biomass was obtained by substracting the weight of the crucible from the weight of the crucible and fungus after drying.

\subsection{Time Course Test for Hydrocarbon Utilization by the Most Active Hydrocarbon-Degrading Microbial Isolates}

The medium used was the mineral salts medium used by Olukunle [13]. The medium was prepared and dispensed in $9 \mathrm{ml}$ amounts in $30 \mathrm{ml}$ test tubes. $1 \mathrm{ml}(1 \%)$ of crude oil was introduced into each tube which was then capped and sterilized in an autoclave at $121^{\circ} \mathrm{C}$ for fifteen minutes. Upon cooling, the microbial isolates were inoculated singly and as the consortia and incubated for thirty five days in a rotary shaker (75rpm). The $\mathrm{pH}$ and viable counts were determined at 7 days intervals using a $\mathrm{pH}$ meter and the plate count method respectively.

\subsection{Determination of Residual Hydrocarbon Content}

The method used by Amadi [17] was adopted. The content of each tube was transferred to a separating funnel at the end of incubation and the residual crude oil was extracted with toluene. The funnel was corked tightly, titled for 5 minutes, shaken and occasionally refluxed to let out air. The samples were allowed to stand for 30 minutes. The toluene-crude oil mixture was collected into a sample bottle and analysed spectrophotometrically by diluting the mixture with a known volume of toluene ( $1 \mathrm{ml}$ of mixture diluted with $9 \mathrm{ml}$ of toluene) and subsequently reading the absorbance at the wavelength of 420nm. A standard graph was prepared using known volume of toluene.

The residual hydrocarbon content was determined from the formula:

$$
\text { Residual hydrocarbon content }=\frac{G R \times I V S}{V t}
$$

Where $\mathrm{Vt}=$ Volume of crude oil applied

IVS $=$ Volume of toluene used for the extraction

$\mathrm{GR}=$ Absorbance reading at $420 \mathrm{~nm} \times$ slope of the standard graph 


$$
\begin{gathered}
\% \text { Residual hydrocarbon content }=\frac{\text { Hydrocarbon recovered }}{\text { Hydrocarbon applied }} \times 100 \\
\% \text { degradation of oil }=\frac{\text { Hydrocarbon applied }- \text { Hydrocarbon recovered }}{\text { Hydrocarbon applied }} \times 100
\end{gathered}
$$

\section{Results}

The heterotrophic and hydrocarbon-utilizing bacteria isolated from the pig manure are presented in Table 1 . They were Escherichia coli, Micrococcus luteus, Enterococcus faecalis, Staphylococcus aureus, Proteus vulgaris, Shigella flexneri, Serratia marcescens and Pseudomonas aeruginosa. Most of the isolates were gram negative rods.

Table 1. Heterotrophic and hydrocarbon-utilizing bacteria isolated from the Pig manure.

\begin{tabular}{|c|c|}
\hline Heterotrophic bacteria & Hydrocarbon-utilizing bacteria \\
\hline Escherichia coli & Micrococcus luteus \\
\hline Micrococcus luteus & Enterococcus faecalis \\
\hline Enterococcus faecalis & Proteus vulgaris \\
\hline Staphylococcus aureus & Shigella flexneri \\
\hline Proteus vulgaris & Serratia marcescens \\
\hline Shigella flexneri & Pseudomonas aeruginosa \\
\hline Serratia marcescens & \\
\hline Pseudomonas aeruginosa & \\
\hline
\end{tabular}

The colonial and microscopic characteristics of the fungi isolated from the pig manure are shown in Table 2. The isolates were identified as Aspergillus niger, Cladosporium resinae, Penicillium expansum, Trichoderma herbarum and Candida tropicalis.

Table 2. Colonial and microscopic characteristics of the fungi isolated from the Pig manure

\begin{tabular}{|c|l|l|c|}
\hline Isolate & \multicolumn{1}{|c|}{ Colonial characteristics } & \multicolumn{1}{|c|}{ Microscopic characteristics } & Identity \\
\hline 1. & $\begin{array}{l}\text { Colonies were initially white but later formed black } \\
\text { conidia. The reverse side was yellowish-grey. }\end{array}$ & $\begin{array}{l}\text { Hyphae were septate. Conidiophores were long, } \\
\text { smooth-walled, hyaline and contained globose } \\
\text { vesicle each covered completely with biseriate } \\
\text { phialides. Conidia were globose, dark and } \\
\text { rough-walled. Conidia heads were large, dark } \\
\text { brown and biseriate. }\end{array}$ & Aspergillus niger \\
\hline 2. & $\begin{array}{l}\text { Colonies were slow growing and dark-green with } \\
\text { black edges. The reverse side was greenish brown. }\end{array}$ & $\begin{array}{l}\text { Conidiophores were erect, unbranched and dark. } \\
\text { Conidia were dark, shield-shaped, smooth and } \\
\text { occurred in long branching chains. }\end{array}$ & Cladosporium resinae \\
\hline 3. & $\begin{array}{l}\text { Dull green mycelia with whitish lining were seen. } \\
\text { Non-septate hyphae were seen }\end{array}$ & Penicillium expansum \\
\hline 4. & $\begin{array}{l}\text { Colonies were slow growing, dark-green with black } \\
\text { edges and powdery. The reverse side was greenish } \\
\text { brown. }\end{array}$ & $\begin{array}{l}\text { Conidiophores were erect, unbranched and dark, } \\
\text { shield-shaped, smooth and occurred in long } \\
\text { branching chains. }\end{array}$ & $\begin{array}{c}\text { Trichoderma } \\
\text { herbarum }\end{array}$ \\
\hline 5. & $\begin{array}{l}\text { Colonies were cream coloured, oval, smooth, soft } \\
\text { and yeast-like in appearance with a yeast odor. }\end{array}$ & $\begin{array}{l}\text { Subspherical budding yeast-like cells called } \\
\text { blastospores were present. }\end{array}$ & Candida tropicalis \\
\hline
\end{tabular}

The screening test result for hydrocarbon utilization by the microbial isolates from the pig manure is shown in Table 3 . All the bacterial isolates except Escherichia coli and Staphylococcus aureus utilized the crude oil while all the fungal isolates utilized the crude oil. Micrococcus luteus and Pseudomonas aeruginosa produced heavy turbidity in the mineral salts-oil medium among the bacterial isolates while Aspergillus niger and Cladosporium resinae produced heavy clarity among the fungal isolates. The bacterial and fungal consortia also produced heavy turbidity and clarity respectively in the mineral salts-oil medium. 
Table 3. Screening test for hydrocarbon utilization by the microbial isolates from the Pig manure

\begin{tabular}{|c|c|}
\hline Microbial isolates & Hydrocarbon utilization \\
\hline Escherichia coli & - \\
\hline Micrococcus luteus & +++ \\
\hline Serratia marcescens & ++ \\
\hline Pseudomonas aeruginosa & +++ \\
\hline Shigella flexneri & ++ \\
\hline Proteus vulgaris & + \\
\hline Staphylococcus aureus & - \\
\hline Enterococcus faecalis & ++ \\
\hline Candida tropicalis & ++ \\
\hline Aspergillus niger & +++ \\
\hline Penicillium expansum & ++ \\
\hline Trichoderma herbarum & ++ \\
\hline Cladosporium resinae & +++ \\
\hline Bacterial consortium & +++ \\
\hline Fungal consortium & +++ \\
\hline
\end{tabular}

$=$ No turbidity for the bacterial isolates

$+=$ Minimal turbidity and clarity for bacteria and fungi respectively $++=$ Moderate turbidity and clarity for bacteria and fungi respectively $+++=$ Heavy turbidity and clarity for bacteria and fungi respectively

The growth of the hydrocarbon-utilizing microbial isolates at varying crude oil concentrations is shown in Table 4. The isolates grew best at $1.0 \%$ crude oil concentration.

Table 4. Growth of the hydrocarbon-utilizing microbial isolates at varying crude oil concentrations.

\begin{tabular}{|c|c|c|c|}
\hline \multirow{2}{*}{ Isolates } & \multicolumn{4}{|c|}{$\begin{array}{c}\text { Growth in varying concentrations } \\
\text { of crude oil (\%) }\end{array}$} \\
\hline Micrococcus luteus & $\mathbf{1 . 0}$ & $\mathbf{5 . 0}$ & $\mathbf{1 0 . 0}$ \\
\hline Enterococcus faecalis & ++ & ++ & + \\
\hline Proteus vulgaris & ++ & + & + \\
\hline Shigella flexneri & ++ & + & + \\
\hline Serratia marcescens & ++ & + & + \\
\hline Pseudomonas aeruginosa & +++ & ++ & + \\
\hline Aspergillus niger & +++ & ++ & + \\
\hline Cladosporium resinae & +++ & ++ & + \\
\hline Penicillium expansum & ++ & + & + \\
\hline Trichoderma herbarum & ++ & + & + \\
\hline Candida tropicalis & ++ & + & + \\
\hline
\end{tabular}

$+=$ Minimal turbidity and clarity for bacteria and fungi respectively. $++=$ Moderate turbidity and clarity for bacteria and fungi respectively. $+++=$ Heavy turbidity and clarity for bacteria and fungi respectively.

The growth of the hydrocarbon-utilizing microbial isolates at varying $\mathrm{pH}$ of medium is presented in Table 5 . The bacteria grew best at neutral $\mathrm{pH}$ (7.0) while the acidic $\mathrm{pH}$ (3.0) favoured the growth of the fungi. None of the isolates grew at the allcaline $\mathrm{pH}(10.0)$.

Table 5. Growth of the hydrocarbon-utilizing microbial isolates at varying $\mathrm{pH}$ of medium.

\begin{tabular}{|c|c|c|c|}
\hline \multirow{2}{*}{ Isolates } & \multicolumn{3}{|c|}{ Growth at varying pH } \\
& $\mathbf{3 . 0}$ & $\mathbf{7 . 0}$ & $\mathbf{1 0 . 0}$ \\
\hline Micrococcus luteus & - & +++ & - \\
\hline Enterococcus faecalis & - & ++ & - \\
\hline Proteus vulgaris & - & ++ & - \\
\hline Shigella flexneri & - & ++ & - \\
\hline Serratia marcescens & - & ++ & - \\
\hline Pseudomonas aeruginosa & - & +++ & - \\
\hline Aspergillus niger & +++ & ++ & - \\
\hline Cladosporium resinae & +++ & ++ & - \\
\hline Penicillium expansum & ++ & + & - \\
\hline Trichoderma herbarum & ++ & + & - \\
\hline Candida tropicalis & ++ & + & - \\
\hline
\end{tabular}

__ = No turbidity and clarity for bacteria and fungi respectively.

$+=$ Minimal turbidity and clarity for bacteria and fungi respectively.

$++=$ Moderate turbidity and clarity for bacteria and fungi respectively.

$+++=$ Heavy turbidity and clarity for bacteria and fungi respectively.

The growth of the hydrocarbon-utilizing microbial isolates at varying concentrations of pig manure is shown in Table 6. The result showed that as the concentration of the manure increased, the microbial isolates also increased in population.

Table 6. Growth of the hydrocarbon-utilizing microbial isolates at varying concentrations of Pig manure.

\begin{tabular}{|c|c|c|c|}
\hline \multirow[t]{2}{*}{ Isolates } & \multicolumn{3}{|c|}{$\begin{array}{c}\text { Growth at varying concentration } \\
\text { of Pig manure }(\mathrm{g} / \mathrm{l}) \text {. }\end{array}$} \\
\hline & 1.0 & 5.0 & 0.0 \\
\hline Micrococcus luteus & 0.39 & 0.47 & 0.63 \\
\hline Enterococcus faecalis & 0.37 & 0.44 & 0.59 \\
\hline Proteus vulgaris & 0.30 & 0.38 & 0.51 \\
\hline Shigella flexneri & 0.28 & 0.35 & 0.50 \\
\hline Serratia marcescens & 0.26 & 0.31 & 0.45 \\
\hline Pseudomonas aeruginosa & 0.31 & 0.39 & 0.53 \\
\hline Aspergillus niger & 3.55 & 4.03 & 4.87 \\
\hline Cladosporium resinae & 3.27 & 3.59 & 3.74 \\
\hline Penicillium expansum & 2.56 & 2.78 & 3.28 \\
\hline Trichoderma herbarum & 2.39 & 2.55 & 2.85 \\
\hline Candida tropicalis & 2.29 & 2.42 & 2.63 \\
\hline
\end{tabular}

Values for bacteria $=$ Optical density at $560 \mathrm{~nm}$ Values for fungi $=$ biomass in grams

The growth of the hydrocarbon-utilizing microbial isolates at varying concentrations of inorganic fertilizer (NPK) is shown in Table 7. The population of the isolates also increased with increasing concentration of the inorganic fertilizer. 
Table 7. Growth of the hydrocarbon-utilizing microbial isolates at varying concentrations of inorganic fertilizer (NPK).

\begin{tabular}{|c|c|c|c|}
\hline \multirow{2}{*}{ Isolates } & \multicolumn{3}{|c|}{$\begin{array}{c}\text { Growth at varying concentration of } \\
\text { inorganic fertilizer (g/l). }\end{array}$} \\
& $\mathbf{1 . 0}$ & $\mathbf{5 . 0}$ & $\mathbf{1 0 . 0}$ \\
\hline Micrococcus luteus & 0.27 & 0.44 & 0.50 \\
\hline Enterococcus faecalis & 0.31 & 0.37 & 0.48 \\
\hline Proteus vulgaris & 0.27 & 0.30 & 0.46 \\
\hline Shigella flexneri & 0.25 & 0.27 & 0.40 \\
\hline Serratia marcescens & 0.23 & 0.26 & 0.38 \\
\hline Pseudomonas aeruginosa & 0.29 & 0.35 & 0.60 \\
\hline Aspergillus niger & 3.37 & 3.61 & 5.00 \\
\hline Cladosporium resinae & 2.64 & 2.98 & 3.47 \\
\hline Penicillium expansum & 2.52 & 2.63 & 3.02 \\
\hline Trichoderma herbarum & 2.28 & 2.36 & 2.61 \\
\hline Candida tropicalis & 2.16 & 2.31 & 2.45 \\
\hline
\end{tabular}

Values for bacteria $=$ Optical density at 560nm

Values for fungi $=$ biomass in grams

The growth profiles of the most active hydrocarbon-degrading bacteria (Pseudomonas aeruginosa and Micrococcus luteus) in mineral salts-oil medium within 35 days are shown in Tables 8 and 9. The viable count increased progressively while there was a decrease in the initial $\mathrm{pH}$ of the broth to the acidic range.

Table 8. Growth profile of Pseudomonas aeruginosa within 35 days in mineral salts-oil medium

\begin{tabular}{|c|c|c|}
\hline Days & Viable count $\left(\mathbf{x 1 0} \mathbf{5}^{\mathbf{c f u}} \mathbf{\text { ml } )}\right.$ & $\mathbf{p H}$ \\
\hline 0 & 4.0 & 7.20 \\
\hline 7 & 4.2 & 7.00 \\
\hline 14 & 4.3 & 6.90 \\
\hline 21 & 4.4 & 6.80 \\
\hline 28 & 4.5 & 6.70 \\
\hline 35 & 4.7 & 6.50 \\
\hline
\end{tabular}

Table 9. Growth of Micrococcus luteus within 35days in mineral salts-oil medium

\begin{tabular}{|c|c|c|}
\hline Days & Viable count $(\mathbf{x 1 0} \mathbf{~} \mathbf{c f u} / \mathbf{m l})$ & $\mathbf{p H}$ \\
\hline 0 & 4.1 & 7.20 \\
\hline 7 & 4.3 & 7.10 \\
\hline 14 & 4.4 & 6.00 \\
\hline 21 & 4.5 & 6.90 \\
\hline 28 & 4.7 & 6.70 \\
\hline 35 & 4.8 & 6.40 \\
\hline
\end{tabular}

The growth profiles of the most active hydrocarbon-degrading fungi (Aspergillus niger and Cladosporium resinae) in the mineral salts-oil medium within 35 days are presented in Tables 10 and 11 . The viable count also increased throughout the period of study while there was also a decrease in the initial $\mathrm{pH}$ of the mineral salts-oil medium.
Table 10. Growth profile of Aspergillus niger within 35 days in mineral salts-oil medium

\begin{tabular}{|c|c|c|}
\hline Days & Viable count $\mathbf{( x 1 0} \mathbf{5} \mathbf{c f u} / \mathbf{m l})$ & $\mathbf{p H}$ \\
\hline 0 & 2.8 & 7.20 \\
\hline 7 & 3.0 & 7.10 \\
\hline 14 & 3.2 & 7.00 \\
\hline 21 & 3.3 & 6.90 \\
\hline 28 & 3.4 & 6.80 \\
\hline 35 & 3.6 & 6.60 \\
\hline
\end{tabular}

Table 11. Growth profile of Cladosporium resinae within 35 days in Mineral salts-oil medium

\begin{tabular}{|c|c|c|}
\hline Days & Viable count $\left(\times 10^{5} \mathrm{cfu} / \mathrm{ml}\right)$ & pH \\
\hline 0 & 2.7 & 7.30 \\
\hline 7 & 2.9 & 7.20 \\
\hline 14 & 3.1 & 7.10 \\
\hline 21 & 3.2 & 7.00 \\
\hline 28 & 3.3 & 6.90 \\
\hline 35 & 3.4 & 6.80 \\
\hline
\end{tabular}

The growth profiles of the bacterial and fungal consortia in the mineral salts oil medium within35 days are shown in Tables 12 and 13. The viable count increased progressively while the $\mathrm{pH}$ also dropped from the initial level.

Table 12. Growth profile of the bacterial consortium within 35 days in mineral salts-oil medium

\begin{tabular}{|c|c|c|}
\hline Days & Viable count $(\mathbf{x 1 0} \mathbf{5} \mathbf{c} \mathbf{u} / \mathbf{m l})$ & $\mathbf{p H}$ \\
\hline 0 & 4.4 & 7.40 \\
\hline 7 & 4.6 & 7.00 \\
\hline 14 & 4.7 & 6.80 \\
\hline 21 & 4.8 & 6.50 \\
\hline 28 & 5.0 & 6.30 \\
\hline 35 & 5.2 & 6.00 \\
\hline
\end{tabular}

Table 13. Growth profile of the fungal consortium within 35 days in mineral salts-oil medium

\begin{tabular}{|c|c|c|}
\hline Days & Viable count $\left(\times 10^{5} \mathrm{cfu} / \mathrm{ml}\right)$ & $\mathbf{p H}$ \\
\hline 0 & 3.2 & 7.40 \\
\hline 7 & 3.4 & 7.20 \\
\hline 14 & 3.6 & 6.90 \\
\hline 21 & 3.7 & 6.60 \\
\hline 28 & 3.8 & 6.40 \\
\hline 35 & 3.9 & 6.30 \\
\hline
\end{tabular}

The percentage degradation of the crude oil by the most active hydrocarbon degrading organisms (Pseudomonas aeruginosa, Micrococcus luteus, Aspergillus niger and Cladosporium resinae) and the microbial consortia are shown in Table 14. Micrococcus luteus degraded the crude oil most actively (40.00\%) among the bacterial isolates while Aspergillus niger degraded the oil most effectively (39.00\%) among the fungal isolates. The bacterial consortia also 
degraded the crude oil more effectively $(62.00 \%)$ than the fungal consortium which degraded $51.00 \%$ of the oil. The microbial consortia degraded the oil better than the individual organisms.

Table 14. Percentage degradation of the crude oil by the most active degraders and microbial consortia at the end of 35 days of growth

\begin{tabular}{|c|c|c|c|}
\hline $\begin{array}{c}\text { Most active } \\
\text { degraders }\end{array}$ & $\begin{array}{c}\text { Initial oil } \\
\text { content (ml) }\end{array}$ & $\begin{array}{c}\text { Final oil } \\
\text { content (ml) }\end{array}$ & $\begin{array}{c}\text { Percentage } \\
\text { degradation }\end{array}$ \\
\hline $\begin{array}{c}\text { Pseudomonas } \\
\text { aeruginosa }\end{array}$ & 1.00 & 0.62 & 38.00 \\
\hline Micrococcus luteus & 1.00 & 0.60 & 40.00 \\
\hline Aspergillus niger & 1.00 & 0.61 & 39.00 \\
\hline $\begin{array}{c}\text { Cladosporium } \\
\text { resinae }\end{array}$ & 1.00 & 0.70 & 30.00 \\
\hline $\begin{array}{c}\text { Bacterial } \\
\text { consortium }\end{array}$ & 1.00 & 0.38 & 62.00 \\
\hline Fungal consortium & 1.00 & 0.49 & 51.00 \\
\hline
\end{tabular}

\section{Discussion}

This study showed that pig manure contains a teaming population of heterotrophic bacteria. The heterotrophic bacteria isolated were Escherichia coli, Micrococcus luteus, Enterococcus faecalis, Staphylococcus aureus, Proteus vulgaris, Shigella flexneri, Serratia marcescens and Pseudomonas aeruginosa (Table 1). Udebuani et al.; [18] studied the value of animal manure in the enhancement of bioremediation processes in petroleum hydrocarbon contaminated agricultural soils and isolated Micrococcus sp., Pseudomonas sp. and Proteus sp. from animal manure. Yakubu [19] studied the biodegradation of Lagoma crude oil using pig dung and reported the presence of the species of Pseudomonas, Proteus and Micrococcus in the dung.

The hydrocarbon-utilizing bacteria isolated from the pig manure were Micrococcus luteus, Enterococcus faecalis, Proteus vulgaris, Shigella flexneri, Serratia marcescens and Pseudomonas aeruginosa (Table 1). Bento et al [20] in their study of the comparative bioremediation of soil contaminated with diesel oil by natural attenuation, biostimulation and bioaugmentation isolated Serratia marcescens and Proteus vulgaris and reported that they had hydrocarbon utilizing potentials. Chikere et al. [21] carried out an assessment of bioreactor-based bioremediation of hydrocarbon polluted Niger Delta marine sediment, Nigeria and reported that there is a high population of active indigenous hydrocarbon-utilizing bacteria that can be monitored and enhanced to bring about bioremediation. They isolated Pseudomonas aeruginosa, Serratia marcescens, Micrococcus luteus and Proteus vulgaris and reported that the bacteria were capable of degrading crude oil polluted soil.

Chikere and Ekwuabu [22] carried out the culture-dependent characterization of hydrocarbon utilizing bacteria in the selected crude-oil impacted sites in Bodo, Ogoniland, Nigeria and reported the presence of Micrococcus luteus, Pseudomonas aeruginosa, Proteus vulgaris and Serratia marcescens which utilized hydrocarbons. Omotayo et al [23] in their work on the degradation of aviation fuel by microorganisms isolated from tropical polluted soils and Yakubu [19] in their work on the biodegradation of Lagoma crude oil using pig dung isolated similar organisms and reported that they had petroleum hydrocarbon-degrading potentials.

The fungi isolated from the pig manure were Aspergillus niger, Cladosporium resinae, Penicillium expansum, Trichoderma herbarum and Candida tropicalis (Table 2). All of them had hydrocarbon degradation potentials. Benal et al [24] in their study of the prevailing fungi on hydrocarbon polluted soil isolated Aspergillus, Pencillium and Cladosporium and reported that they had hydrocarbon degrading capabilities. Chikere and Azubike [25] in their work on the characterization of hydrocarbon-utilizing fungi from hydrocarbon polluted sediments and water isolated Aspergillus, Penicillium, Cladosporium and Candida. Omotayo et al [23] also isolated Candida tropicalis from tropical polluted soils and reported that it degraded aviation fuel while Candida spp. have been reported by Amund and Nwokoye [26] to utilize oil.

Ichor et al [27] studied the biodegradation of total petroleum hydrocarbon by aerobic heterotrophic bacteria from crude oil-contaminated brackish waters of Bodo Creek and identified Enterobacter sp. and Pseudomonas sp. Douglas and Isor [28] isolated Enterobacter sp., Pseudomonas sp. and Micrococcus sp. from pond water in Ogoni while Atobatele and Owoseni [29] isolated Escherichia sp. and Enterobacter sp. from fresh water body in Iwo, Osun State, Nigeria. Latha and Kalaivani [30] studied the bacterial degradation of crude oil by gravimetric analysis and reported that bacteria contribute largely in the degradation of hydrocarbons and its compounds.

The isolates Pseudomonas aeruginosa and Micrococcus luteus produced heavy turbidity among the bacterial isolates while Aspergillus niger and Cladosporium resinae also produced heavy clarity among the fungal isolates. In addition, the bacterial and fungal consortia also produced heavy turbidity and clarity respectively in the mineral salts-oil medium (Table 3) which indicated heavy growth. Sathishkumar et al. [31] studied the biodegradation of crude oil by individual bacterial strains and a mixed bacterial consortium isolated from hydrocarbon and reported that bacteria showed higher degradation when used as a consortium than as individual isolates. Santos and Linardi [32] studied the biodegradation of phenol by a filamentous fungus isolated from the soil and reported Aspergillus niger as a high hydrocarbon utilizer.

The result of the growth of the hydrocarbon-utilizing microbial isolates at varying crude oil concentrations (Table 4)showed that their rate of growth was highest at low oil concentration (1.0\%) than at high oil concentrations $(5.0 \%$ and $10.0 \%$, hence $1.0 \%$ oil concentration was optimal for their growth. This result conformed to the findings of Amadi and Antai [14] who studied the quantitative estimation of the growth and survival of some petroleum hydrocarbon 
degrading microorganisms as affected by microbial cultures and reported that the isolates grew best at $1.0 \%$ crude oil concentration.

The growth response of the hydrocarbon-utilizing microbial isolates in mineral salts medium at varying $\mathrm{pH}$ levels (Table 5) showed that at acidic and alkaline $\mathrm{pH}$ levels (3.0 and 10.0 respectively), the bacterial isolates did not grow. However, at $\mathrm{pH}$ 7.0, they grew well. On the other hand, the fungal isolates grew at both $\mathrm{pH} 3.0$ and 7.0 but failed to grow at $\mathrm{pH}$ 10.0. This result indicated that $\mathrm{pH} 3.0$ was most favourable to the growth of the fungal isolates while $\mathrm{pH} 7.0$ was most favourable to the growth of the bacterial isolates.

This result agreed with the observations of Amadi and Antai [14] who reported that low $\mathrm{pH}$ levels towards the acidic range tend to favour more petroleum hydrocarbon utilizing fungi than bacteria while at the neutral range, both bacteria and fungi are stimulated. Okpokwasili and Okorie [33] reported that bacteria are the principal biodeteriogens of oil when the $\mathrm{pH}$ is near neutral, but they give way to moulds and yeast as the $\mathrm{pH}$ becomes acidic. The proliferation of the hydrocarbon-utilizing microbial isolates at $\mathrm{pH} 7.0$ in this study suggested that it is the $\mathrm{pH}$ range most favourable to them.

The growth responses of the hydrocarbon-utilizing microbial isolates at varying concentrations of Pig manure and inorganic fertilizer (NPK) showed that there was a general increase in cell numbers for bacteria and biomass for fungi depending on the type and nutrients concentrations. This result agreed with the findings of Jobson et al [34] who reported that in near Arctic soils in the normal wells and Swan hills areas of Canada, the addition of fertilizer increased rates of biodegradation.

Adieze et al. [35] reported that addition of both organic and inorganic nutrient supplement resulted in the stimulation of bacterial growth in the oil-contaminated soil. Chikere and Okpokwasili [36] also reported the enhancement of growth of Pseudomonas sp., Bacillus sp., Serratia sp., Micrococcus $s p$. and Alcaligenes sp. as a result of nutrient supplementation and attributed it to the fact that the supplements contain carbon, energy and mineral nutrients such as nitrogen, phosphorus and sulphur which are essential for microbial growth as well as the synthesis of amino acids in microorganisms. In this study, Pig manure supported the growth of the microbial isolates more than the inorganic fertilizer.

The $\mathrm{pH}$ and the viable count of the most active hydrocarbon degrading bacteria and fungi (Pseudomonas aeruginosa, Micrococcus luteus, Aspergillus niger and Cladosporium resinae) and the bacterial and fungal consortia in mineral salts-oil medium during 35 days of growth showed that the microbial consortia had lower $\mathrm{pH}$ values and increased viable counts than the individual isolates (Tables 8-13). The increase in viable count indicated growth, probably leading to the production of by-products as a result of metabolism. Rahman et al. [37] reported that the utilization of crude oil as the sole source of carbon and energy by hydrocarbon degrading microorganisms resulted in their growth with a concomitant production of acidic metabolites which might account for the decrease in the $\mathrm{pH}$ of the cultures.

The bacterial and fungal consortia exhibited higher percentage degradation of the crude oil than the individual bacterial and fungal isolates (Table 14). Several researchers have reported that bacterial consortium degrade hydrocarbon better than individual isolates [37, 38, 39]. Friello et al. [40] reported that a wide variety of metabolic and physiological factors are required for the degradation of different compounds in diesel oil and that all of such properties are not found in one organism. Adebusoye et al. [41] demonstrated that mixed culture of microbial community is required to complete degradation of oil pollutants because the hydrocarbon mixture differs markedly in volatility, solubility and susceptibility to degradation and the necessary enzymes needed cannot be found in a single organism.

Bordenave et al. [42] reported that individual microorganisms metabolize only a limited range of hydrocarbon substrates and crude oil is made up of a mixture of compounds, so its degradation requires a mixture of different microbial consortia. The advantages of mixed cultures in bioremediation have also been widely demonstrated [43, 44, 45, and 46]. It could be attributed to the effects of synergistic interactions of the different microorganisms. Some species are able to remove the toxic metabolites, which hinder the activities of the other species. In this work, the microbial consortia degraded the crude oil better than the individual organisms.

There was a significant difference in the performance of the organisms when used singly and as bacterial and fungal consortia in the degradation process $(\mathrm{P}=0.025)$. In addition there was a significant negative correlation between the viable count and the final oil content $(\mathrm{P}=0.023)$.

\section{Conclusions}

This work showed that bacteria and fungi which are capable of degrading crude oil, leading to environmentally-friendly products are abundant in pig manure. These organisms when applied singly and as consortia can be used to clean up hydrocarbon-polluted environments. However, the bacteria were observed to be better degraders than the fungi.

\section{REFERENCES}

[1] W. Abraham. Microbial Epoxidation: Application in Biotechnology. CRC Press, Germany, 181-203, 2000. DOI: 10.1201/9781420027242.ch7

[2] G.R. Achong, A.M. Rodriguez, A.M. Spormann. BenzyIsuccinate synthase of Azoarcus sp. strain T: cloning, sequencing, transcriptional organization and its role in anaerobic toluene and m-xylene mineralization. Journal of 
Bacteriology. Vol.183, No.23, 6763-6770, 2001. DOI: 10.1128/JB.183.23.6763-6770.2001

[3] A.A. Amin, R. Altee, F.N. Alkanany. Improving oil biodegradability of aliphatic crude oil fraction by bacteria from oil polluted water. African Journal of Biotechnology. Vol.13, No.11, 1243-1249, 2014. DOI: 10.5897/AJB2013.13151

[4] P. Agamuthu, Y.S. Tan, S.H. Fauziah. Bioremediation of hydrocarbon contaminated soil using selected organic wastes. Procedia Environmental Sciences. Vol.18, 694-702, 2013. doi: 10.1016/j.proenv.2013.04.094

[5] E.R. Nikunen, B. Leinonen, A. Kemiliainen, A. Kultamaa. Environmental Properties of Chemicals, $2^{\text {nd }}$ edition, Finish Environment institute, Helsinki. Pp. 302-337, 2000.

[6] E. Pettersson, J. Lundeberg, A. Ahmadian. Generations of sequencing technologies. Genomics. Vol. 93, No.2, 105-111, 2008. DOI: 10.1016/j.ygeno.2008.10.003

[7] A.I. Okoh. Biodegradation alternative in the cleanup of petroleum hydrocarbon pollutants. Biotechnology and Molecular Biology Review. Vol.12, 38-50, 2006. www.sciepub.com/conference/16632

[8] G.C. Okpokwasili, B.B. Okorie. Influence of Physicochemical stress on biodegradability of car engine lubrication oil. International Biodeterioration. Vol.27, No.3, 255-264, 1991. http://dx.doi.org/10.1016/0265-3036(91)90054-U

[9] S.E. Agarry, C.N. Owabor, R.O. Yusuf. Bioremediation of soil artificially contaminated with petroleum hydrocarbon oil mixtures: evaluation of the use of animal manure and chemical fertilizer. Bioremediation Journal. Vol.14, No.4, 189-195, 2010. http://dx.doi.org/10.1080/10889868.2010.514965.

[10] K.M. Ukaegbu-Obi, C.C. Mbakwem-Aniebo. Bioremediation Potentials of bacteria isolated from Rhizosphere of some plants of oil contaminated soil of Niger Delta. Journal of Applied and Environmental Microbiology. Vol.2, No.4, 194-197, 2014 DOI: 10.12691/jaem-2-4-13.

[11] Onuorah Samuel, Obika Ifeanyi, Orji Michael, Odibo Frederick. Microbial contaminants in the commercial Aviation fuel obtained from Benin City Airport, Nigeria. Universal Journal of Microbiology Research. Vol.3, No.3, 31-35, 2015. DOI:10.13189/ujmr.2015.030301

[12] M. Cheesbrough. Laboratory manual. District laboratory practice in tropical countries. Cambridge University Press, United Kingdom. Pp.145-157, 2006.

[13] O. F. Olukunle. Characterization of indigenous microorganisms associated with crude oil-polluted soils and water using traditional techniques. Microbiology Journal. Vol.3, 1-11, 2013. DOI: 10.3923/mj.2013.1.11

[14] A. Amadi, S.P Antai. Quantitative estimation of growth and survival of some petroleum hydrocarbon degraders as affected by microbial cultures. International Journal of Biochemical Physics. Vol.1, No.2, 5-8, 1991.

[15] A.L. Mills, C.Y. Breuil, R.R. Colwell. Enumeration of petroleum degrading marine and estuarine microorganisms by the most probable number method. Canadian Journal of Microbiology. Vol. 24, No. 5, 552-557, 1978. DOI: $10.1139 / \mathrm{m} 78-089$

[16] S.C. Amanchukwu, A. Obafemi, G.C. Okpokwasili. Hydrocarbon degradation and utilization by a palm wine yeast isolate. FEMS Microbiology letters. Vol. 57, No.2, 151-154, 1980. DOI: 10.1111/j.1574-6968.1989.t603290.x

[17] A. Amadi. An assessment of the performance of some petroleum hydrocarbon-degrading microorganisms in aqueous axenic cultures. Discovery and Innovation. Vol.4, No.4, 61-67, 1992. www.africabib.org/rec.php? RID $=\mathrm{Q} 00007931 \& D B=P$

[18] A.C. Udebuani, C.I. Okoli, H.C. Nwigwe, P.T.E. Ozoh. The value of animal manure in the enhancement of bioremediation processes in petroleum hydrocarbon contaminated agricultural soils. Journal of Agricultural Technology. Vol.8,No.6, 1935-1952, 2012 http://www.ijat-aatsea.com

[19] M.J. Yakubu. Biodegradation of lagoma crude Oil using Pig dung. African Journal of Biotechnology. Vol.6, No.24, 2821-2825, 2007 www.sciepub.com/reference/162397

[20] F.M. Bento, F.A.O. Camargo, B.C. Okeke, W.T. Frankenberger. Comparative bioremediation of soils contaminated with diesel oil by natural attenuation, biostimulation and bioaugmentation. Bioresource Technology. Vol. 96, No. 9, 1049-1055, 2005. DOI: 10.1016/j.biortech.20 04.09.008

[21] C.B. Chikere, B.O. Chikere, G.C. Okpokwasili. Bioreactor-based bioremediation of hydrocarbon-polluted Niger Delta marine sediment, Nigeria. Biotechnology. Vol.2, No.1, 53-66, 2012. DOI: 10.1007/s13205-011-0030-8

[22] C.B. Chikere, C.B. Ekwuabu. Molecular characterization of autochthonous hydrocarbon-utilizing bacteria in oil-polluted sites at Bodo Community, Ogoniland, Niger Delta, Nigeria. Nigerian Journal of Biotechnology. Vol.27, 28-33, 2014 http://www.ajol.info/index/php/njb/index

[23] A.E. Omotayo, A.O. Efetie, G.O. Oyetibo, M.O. Ilori, O.O. Amund. Degradation of aviation fuel by microorganisms isolated from tropical polluted soils. International Journal of Biological and Chemical Sciences. Vol.5, No.2, 698-708, 2011 DOI: 10.4314/ijbcs.v5i2.72133

[24] T. Benal, K. Shivani, R.L. Pagare, S. Chitnis. Study of prevailing deuteromycetous fungi on the petro-polluted soil. International Research Journal of Biological Sciences. Vol. 3, No. 11, 28-31, 2014. www.isca.in/IJBS/Archive/v3/i11/7.IS CA-IRJBS-2014-169.php.

[25] C.B. Chikere, C.C. Azubike. Characterization of hydrocarbon-utilizing fungi from hydrocarbon-polluted sediments and water. Nigerian Journal of Biotechnology. Vol. 27, 49-54, 2014. http://www.ajol.info/index.php/njb/index.

[26] O.O. Amund, N. Nwokoye. Hydrocarbon degrading potentials of yeast isolates from a polluted lagoon. Journal of Scientific Research and Development. Vol. 1, 65-69, 1993. repository.unilag.edu.ng/bitstream/123456789/788/1.

[27] T.Ichor, P.O. Okerentugba, G.C. Okpokwasili. Biodegradation of total petroleum hydrocarbon by aerobic heterotrophic bacteria from crude oil contaminated brackish waters of Bodo Creek. Journal of Bioremediation and Biodegradation. Vol.5, N0.5, 236-241, 2014. http://dx.doi.org/10.4172/2155-6199.1000236.

[28] S.I. Douglas, F.N. Isor. Bacteriological investigation of pond water quality from Ogoniland, Nigeria. 10SR Journal of Environmental Science, Toxicology and food Technology. www.iosrjournals.org.

[29] O.E. Atobatele, A.A. Owoseni. Distribution and diversity of 
bacteria in a small tropical fresh water body (Aiba Reservoir) in Iwo, Osun State, Nigeria. Nature and Science. Vol.10, No.12, 92-97, 2012. http://www.sciencepub.net/nature.14

[30] R. Latha, R. Kalaivani. Bacterial degradation of crude oil by gravimetric analysis. Advances in Applied Science Research. Vol.3, No.5, 2789-2795, 2012 www.sciepub.com/reference/103470.

[31] M. Sathishkumar, A.R. Binupriya, S.Baik, S.Yun. Biodegradation of crude oil by individual bacterial strains and a mixed bacterial consortium isolated from hydrocarbon contaminated areas. CLEAN-Soil Air Water. Vol.36, No.1, 92-96, 2008. DOI: 10.1002/clen.200700042

[32] V.L. Santos, V.R. Linardi. Biodegradation of phenol by a filamentous fungus isolated from industrial effluents identification and degradation potential. Processes in Biochemistry. Vol.39, No.8, 1001-1006, 2004. DOI: 10.1016/S0032-9592(03)00201-2

[33] G.C. Okpokwasili, B.B. Okorie. Biodeterioration potentials of microorganisms isolated from car engine lubricating oil. Tribology International. Vol.21, No.4, 215-200, 1988. DOI: 10.1016/0301-679X(88)90020-5

[34] A.m. Jobson, M. Mclaughlin, F.D. Cook, D.W.S. Westlake. Effects of amendments on the microbial utilization of oil applied to soil. Applied and Environmental Microbiology. Vol.27, No.1, 166-171, 1974. https://www.ncbi.nlm.nih.gov/pubmed/4589125

[35] I.E. Adieze, R.N. Nwabueze, G.O.C. Onyeze. Effect of poultry manure on the microbial utilization of hydrocarbons in oil-polluted soil. Nigerian Journal of Microbiology. Vol. 17, No.1, 12-16, 2003.

http://www.researchgate.net/publication/232632133

[36] B.O. Chikere, G.C. Okpokwasili. Enhancement of biodegradation of petrochemicals by nutrient supplementation. Nigeria Journal of Microbiology. Vol.17, No.2, 130-135, 2003.

[37] K.S.M. Rahman, T. Rahman, P. Lakshmanaperumalsamy, I.M. Banat. Towards efficient crude oil degradation by a mixed bacterial consortium. Bioresource Technology. Vol.85, No.3, 257-261, 2002. DOI: 10.1016/S0960-8524(02)00119-0.

[38] A.K. Onifade, F.A. Abubakar. Characterization of hydrocarbon-degrading microorganisms isolated from crude oil contaminated soil and remediation of the soil by enhanced natural attenuation. Research Journal of Microbiology. Vol.2, No.2, 149-155, 2007. DOI: 10.3923/jm.2007.149.155

[39] H. Wang, R. Xu, F. Li, J. Qiao, B. Zhang. Efficient degradation of lube oil by a mixed bacterial consortium. Journal of Environmental Sciences. Vol.22, No.3, 381-388, 2010. DOI: 10.1016/S1001-0742(09)60119-4

[40] D.A. Friello, J.R. Mylroie, A.M. Chakrabaty. Use of genetically engineered multi-plasmid microorganisms for rapid degradation of fuel hydrocarbon. International Biodeterioration and Biodegradation. Vol.48, No.1, 233-242, 2001. DOI: 10.1016/So964-8305(01)00087-7

[41] S.A. Adebusoye, M.O. Ilori, O.O. Amund, O.D. Teniola, S.O. Olatope. Microbial degradation of petroleum hydrocarbons in a polluted tropical stream. World Journal of Microbiology and Biotechnology. Vol.23, No.8, 1149-1159, 2007. DOI: 10.1007/s11274-007-9345-3

[42] S. Bordenave, M.S. Goni-Urriza, P. Caumette, R. Duran. Effects of heavy fuel oil on the bacterial community structure of a pristine microbial mat. Applied and Environmental microbiology. Vol.73, N0.19, 6089-6097, 2007. DOI: 10.1128/AEM.01352-07

[43] L.F. Surzhko, M.I. Yankevich, V.I. Yakovlev. Utilization of oil in soil and water by microbial cells. Microbiology. Vol.64, No.3, 393-398, 1995. https://www.researchgate.net/publication/236573604

[44] S.Komukai-Nakamura, K. Sugiura. Y. Yamauchi-Inomata. H. Toki, K. Venkateswaran, S. Yamamoto, H. Tanaka, S. Harayama. Construction of bacterial consortia that degrade Arabian Light Crude Oil. Journal of Fermentation and Bioengineering. Vol. 82, No.6, 570-574, 1996. DOI: 10.1016/S0922-338x (97)81254-8

[45] D. Koma, Y. Sakashita, K. Kubota, Y. Fujii, F. Hasumi, S. Chung, M. Kubo. Degradation of car engine base oil by Rhodococcus sp. NDKK $K_{48}$ and Gordonia sp. NDKY 6 . Bioscience Biotechnology and Biochemistry. Vol.67, No.7, 1590-1593, 2003. DOI: 10.1271/bbb.67.1590

[46] U.J.J. Ijah, S.P. Antai. Removal of Nigerian light Crude oil in soil over a 12-month period. International Biodeterioration and Biodegradation. Vol. 51, No. 2, 93-99, 2003. DOI: 10.1016/S0964-8305(01)00131-7. 